\title{
NÁLEZ FRAGMENTU KACHLE Z KOLEKCE TZV. RYTÍŘSKÝCH KAMEN V LITOVLI
}

\author{
LUKÁŠ HLUBEK - KAREL FALTÝNEK - PAVEL ŠLÉZAR
}

\begin{abstract}
Abstrakt: Během archeologického výzkumu na Boskovicově ulici v Litovli se podařilo nalézt zlomek hnědě glazovaného kachle, který můžeme přřradit ke skupině kamnářské keramiky z kolekce tzv. rytírských kamen. Ty mají svůj původ v budinské dilně a byly jimi vybaveny rezidence uherského krále Ladislava Pohrobka a jeho přednich dvořanů. Některé z těchto kachli registrujeme také v několika připadech i na našem území. Fragment z Litovle dokládá výskyt těchto exkluzivních kamnářských výrobků na střední Moravě v průběhu druhé poloviny 15. až počátku 16. století. Zároven̆ lze předpokládat vyšši sociální status objednatele těchto kachlů.
\end{abstract}

Klíčová slova: Litovel - kachle-rytířská kamna - druhá polovina 15. až počátek 16. století.

\section{The Find of a Tile Fragment from the Collection of "Knight" Stoves in Litovel}

\begin{abstract}
Archaeological research in Boskovicova Street, Litovel yielded a fragment of a tile with a brown glaze. The fragment can be placed with a group of stove tile ceramics from the collection of "knight" stoves. These tiles were made in a workshop in Buda and were employed in the residences of Hungarian King Ladislaus the Posthumous and his courtiers. Some of these tiles also occur in Czech territory. The fragment from Litovel confirms the occurrence of these exclusive products in central Moravia in the second half of the 15th century and the early 16th century. At the same time, it indicates a high social status of the person that commissioned their manufacture.
\end{abstract}

Key words: Litovel - tile - knight stove - second half of the 15th century-early 16th century.

\section{Úvod}

Výrazný nárůst počtu archeologických výzkumů v areálu města Litovle můžeme sledovat od roku 1997 (k tomu Faltýnek-Šlézar 2006, 303-304). Přestože se podrobné vyhodnocení těchto terénních aktivit teprve rozbíhá, už dnes máme $\mathrm{k}$ dispozici značné množství poznatků o tomto městě (např. Šlézar 2008; 2008a; Šlézar et al. 2008; Faltýnek 2012; 2012a; Faltýnek-Šlézar 2014; ad.). Původní centrum Litovle, označované v písemných pramenech jako „antiqua civitas“ (Staré město), se nacházelo v meandru řeky Moravy. Zhruba v polovině 13. století došlo k translaci tohoto centra do prostoru současného jádra Litovle (nap̌r. Šlézar 2005; 2008a, 10-19).

Lokací města byl pověřen Heinricus řečený Epich, který poté litovelské rychtářství obdržel darem od Přemysla Otakara II. Ještě v polovině 13. století bylo vybudováno dřevohlinité opevnění, skládající se z př́íkopu, valu a palisády. Výstavbu kamenné hradby povolil Litovli roku 1327 český král Jan Lucemburský (např. Smyčka 1914, 71-76). V průběhu druhé poloviny 13. století máme doloženy také zděné sakrální objekty, a to farní kostel sv. Marka a špitál sv. Ducha (Šlézar 2008a, 53-55). Již od počátku byl osídlen celý prostor pravidelně vyměřeného města. Prakticky po celý středověk byla zástavba dřevohlinitá, nebot' vysoká hladina spodní vody ani neumožňovala větší zahlubování staveb pod terén. Právovárečné domy se nacházely především na dnešním náměstí Přemysla Otakara (Smyčka 1914, 76-77, 357-361). Archeologické výzkumy doložily, at' už přímo či nepř́ímo, celou řadu řemesel, jako např. ševcovství, pasířství, kovářství, zámečnictví, hrnčířství, pekařství, řeznictví, dřevozpracující a kost’ařskou výrobu. Velký př́inos pro hospodářství Litovle představovala také řeka Morava, která mohla být využívána k rybolovu, splavování dřeva, transportu zboží i osob; z písemných pramenů také vyplývá, že už roku 1287 pracovaly na řece mlýny (Dehnerová-Šlézar-Zatloukal 2007, 38-43; Šlézar 2008a, 29-34, zde i další literatura).

V současné době probíhá postupné zpracování souborů kamnářské keramiky z areálu města Litovle, a to jak ze sbírky bývalého Okresního vlastivědného muzea v Litovli (např. Hlubek 2013; 2013a), tak i z výzkumů vedených pracovníky Národního památkového ústavu, územního odborného pracoviště v Olomouci. V kolekci kachlů ze záchranného výzkumu na Boskovicově ulici byl identifikován fragment hnědě glazovaného kachle, který lze přiřadit ke kolekci tzv. rytířských kamen. Podobné nálezy evidujeme pouze z několika lokalit na Moravě a v Čechách a obvykle jsou spojovány s vyšším sociálním prostředím. 


\section{Nálezová situace na Boskovicově ulici}

Záchranný výzkum na Boskovicově ulici (obr. 1) proběhl v lednu roku 2001 v souvislosti s budováním kanalizace. Výkop dosáhl celkové délky téměř $53 \mathrm{~m}$ a šířky $0,7 \mathrm{~m}$. Maximální hloubka výkopové rýhy činila $1,65 \mathrm{~m}$, ale nikde nebylo dosaženo intaktního podloží. Nejstarší prozkoumané kulturní vrstvy náležely do první poloviny 14. století. Toto datování potvrdil i následný dendrochronologický rozbor. Z objeveného kulatého kmene (kont. č. 125) bylo získáno absolutní datum 1340. Podařilo se odtud také vyzvednout negativy kostěných vývrtků, naznačující výrobu růženců v Litovli ve druhé polovině 14 . věku. Mladší vrstvy obsahovaly velké množství nálezů organického původu, osteologického a keramického materiálu z 15. až 16. století. Z různých míst výkopu pocházejí také pozdně gotické až renesanční kachle (Faltýnek 2002, 267-268).

Fragmentární soubor 44 kusů kamnářských výrobků se nacházel v celé délce výkopu, a tím pádem lze hovořit pouze o kolekci kachlů, které však spolu mohou, ale také nemusí, souviset. $Z$ těchto důvodů uvedeme pouze stručnější popis a charakteristiku všech exemplářù. $V$ drtivé většině případů je můžeme zařadit do druhé poloviny 15 . až počátku 16. století. Jen tři kusy náleží do průběhu 16., popřípadě počátku 17. věku. V souboru se vyskytl pouze jeden exemplář nádobkového kachle s vnitřní okrajovou lištou a vodorovně seřezaným okrajem. Všechny ostatní fragmenty náleží komorovým kachlům.

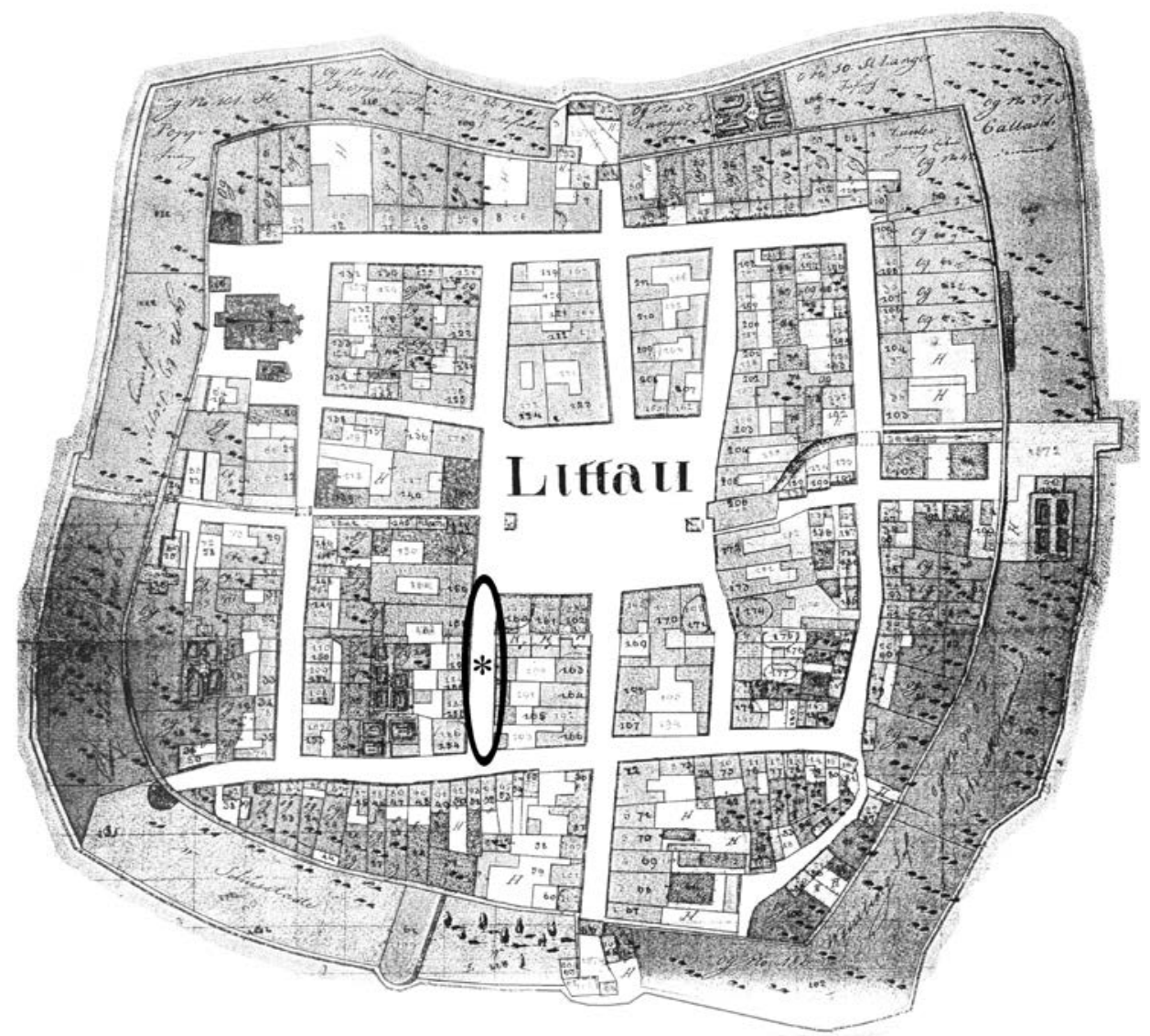

Obr. 1. Litovel. Vyznačení polohy Boskovicovy ulice na indikační skice města z roku 1834. Podle Kauerová-Koudela 1998. Abb. 1. Litovel. Kennzeichnung der Lage Boskovicova-Str. auf einer Indikationsskizze der Stadt aus dem Jahr 1834. Nach Kauerová-Koudela 1998. 
Kategorii heraldických motivů reprezentují tři zlomky s erbem pánů z Vlašimi (obr. 2:1, 3, 6), typ č. I podle L. Hlubka (2012, 87; 2013, 339-341). Na dalších desíti exempláŕích registrujeme stočené fanfrnochy či část helmu, bez možnosti přesnějšího určení. Náboženský námět evidujeme na dvou fragmentech s neúplným reliéfem sv. Jiří (obr. 2:5). Ornamentální motivy nelze blíže specifikovat; nejlépe dochovaná je část rozety (obr. 2:2). Ke skupině architektonických motivů přiřazujeme tři blíže neurčitelné kusy a jeden hnědě glazovaný fragment náležící ke kolekci tzv. rytířských kamen (obr. 3). Pro úplnost dodáme, že na jednom raně novověkém kamnářském

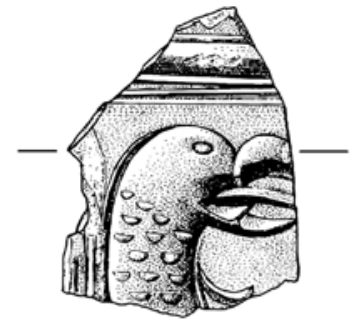

1

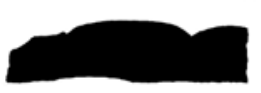

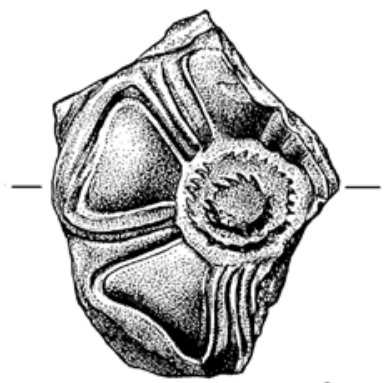

2

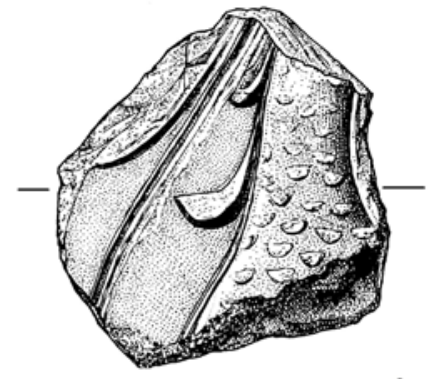

3

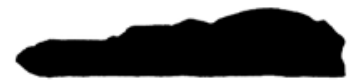

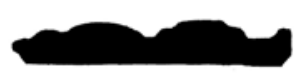
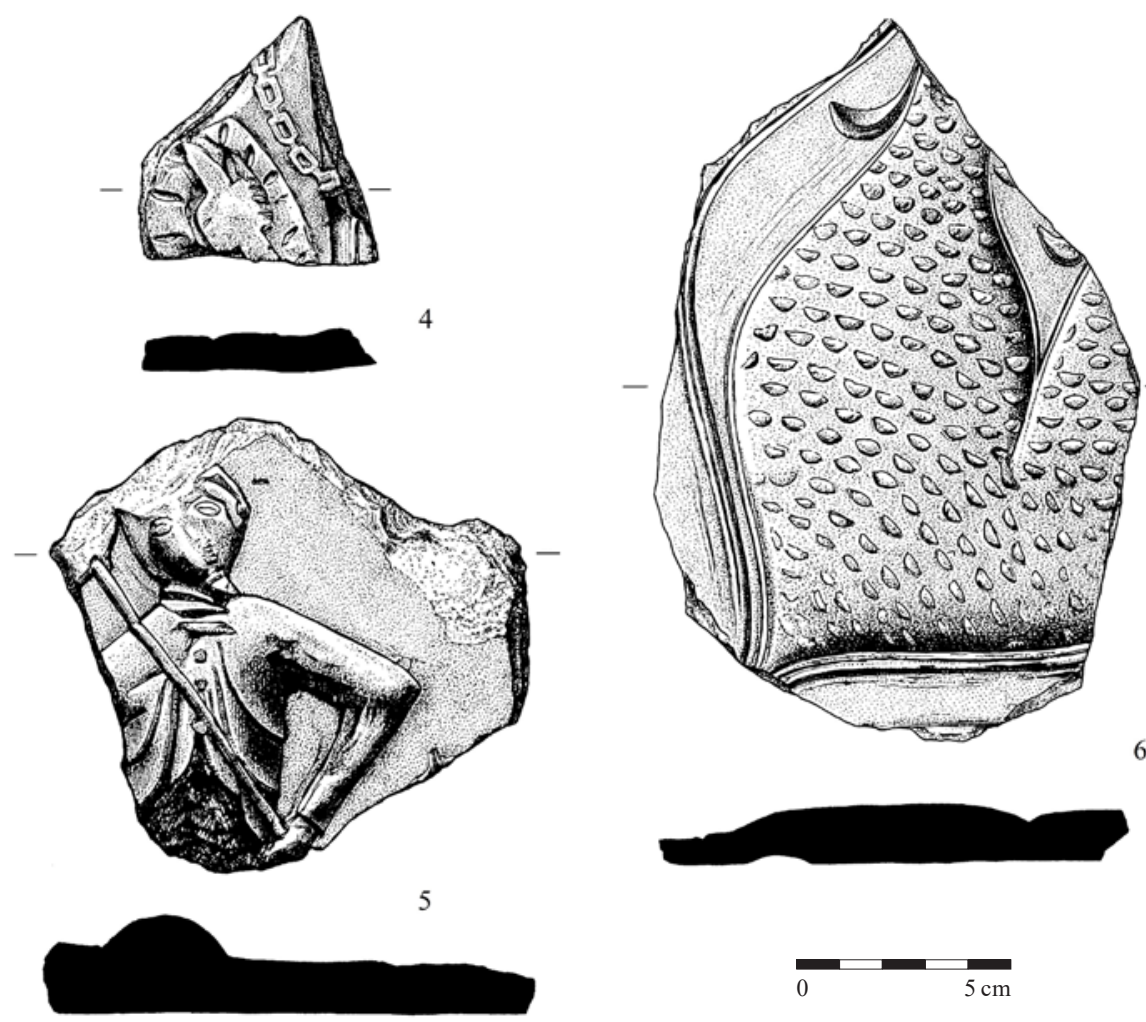

6

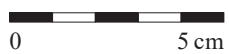

Obr. 2. Litovel. Výběr kamnářské keramiky z výzkumu na Boskovicově ulici. Kresba I. Hradilová.

Abb. 2. Litovel. Auswahl an Ofenkeramik von der Grabung in der Boskovicova-Str. Zeichnung I. Hradilová. 
výrobku zaznamenáváme část polopostavy muže, který třímá žezlo (?) a okolo krku mu visí masivní řetěz (obr. 2:4). Zbylé neuvedené zlomky kachlů nelze prriřknout $\mathrm{k}$ žádné $\mathrm{z}$ kategorií výzdobných motivů.

\section{Popis zlomku kachle z kolekce tzv. rytíř- ských kamen}

Na prezentovaném fragmentu se dochovala pouze horní prořezaná část kachle s oslím hřbetem zdobeným sukovatkou a kraby (obr. 3). Pod obloukem visí torzo okenní kružby, které už ale není prořezáno (srov. obr. 3:a, b). Povrch zlomku je opatřen kvalitní oboustrannou kaštanově hnědou glazurou, na některých místech dnes už značně poškozenou. Pod ní je patrná písčitá až béžová barva kachle, ale bez vrstvičky bílé hlinky (obr. 3:a, b). Představený kus byl vyroben $\mathrm{z}$ písčitého materiálu s velkým množstvím drobných kaménků o velikosti ca $1 \mathrm{~mm}$. Rozměry popisovaného nálezu činí: maximální výška $60 \mathrm{~mm}$, šířka $49 \mathrm{~mm}$ a síla stěny až $13 \mathrm{~mm}$.

$\mathrm{Na}$ základě dochování litovelského zlomku lze usuzovat, že podle typologie kachlů I. Holla odpovídá typu č. 3 (srov. Holl 1958, 255, 76 kép., 291-292; 1998, 141-144, Abb. 5), což je patrné prredevším při srovnání prezentovaného zlomku s kachlem tohoto typu (srov. obr. 4). Je také zřejmé, že jde o levou
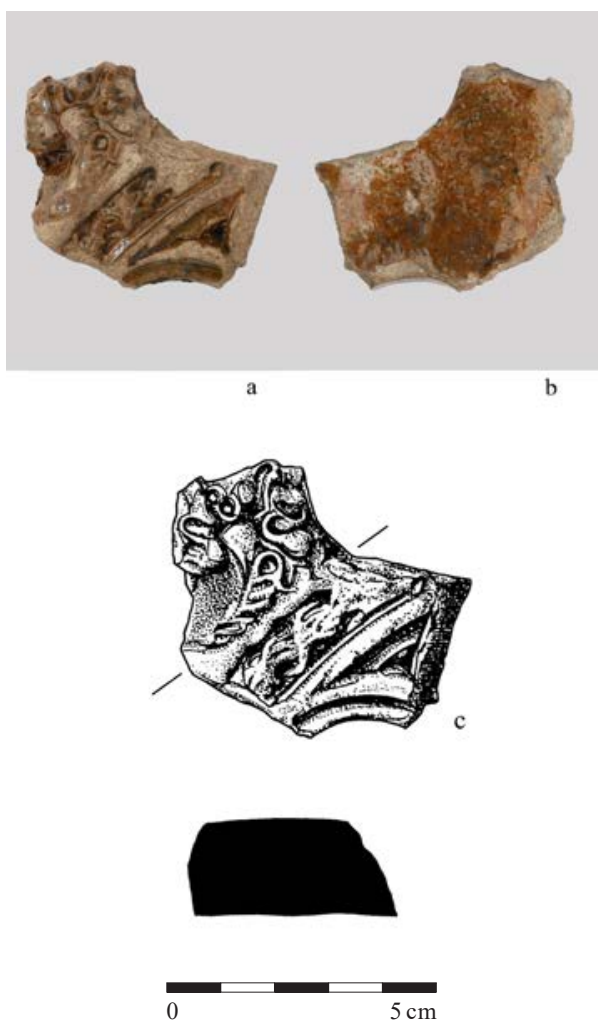

Obr. 3. Litovel. Zlomek kachle tzv. uherské skupiny. Foto P. Rozsíval, kresba I. Hradilová.

Abb. 3. Litovel. Kachelfragment der sog. ungarischen Gruppe. Foto P. Rozsíval, Zeichnung I. Hradilová. stranu oslího oblouku z míst v blízkosti okraje.

V dalším textu se již budeme zabývat pouze kachli typu č. 3 (dle I. Holla 1958, 255, 76 kép., 291-292), popř́ípadě blízkého typu č. 4 (srov. Holl 1958, 257, 79 kép., 292; 1998, 144-146, Abb. 6). Stranou tak ponecháme ostatní reliéfy a výzdobné motivy, které se objevují u této výrazné skupiny kachlů spojovaných s budínskou dílnou či jsou od ní odvozeny (k tomu napr. Michna 1971, 249-258; 1977, 18-24; 1998, 12; Jordánková-Loskotová 2002, 559-560; Jordánková-Loskotová-Merta 2004, 581-582, 588; Loskotová 2008, 529-533; Menoušková 2009, 232-234, obr. 7-8; Merta-Peška 2010, 402, obr. 4; Loskotová-Menoušková 2010, 408-410, obr. 6; Loskotová 2012, 193-195, obr. 1; ad.).

\section{Kolekce kachlů tzv. rytířských kamen}

Za kachle z kolekce tzv. rytířských kamen jsou označovány kachle vyráběné v budínské dílně mezi lety 1454 a 1457 pro potřeby uherského a českého krále Ladislava Pohrobka. Soubor pozdně gotických kachlů, ze kterých byla stavěna luxusní otopná tělesa, obsahoval devět základních typů charakteristických bohatostí plastického ornamentu. Čelní plochy některých exemplářů výrobci kamen prořezali do tvaru gotických lomených oken a portálů. Jeden z nich (typ č. 5 dle I. Holla 1958, 258, 80 kép. 292) má ve vzniklé dutině figuru rytíře v charakteristické turnajové pozici na cválajícím koni. Právě tento exemplář s rytířem na koni dal celé kolekci jméno - rytíř ská kamna. Souborem těchto kachlů byly vybaveny jak královské rezidence, tak sídla vybraných uherských světských i církevních představitelů (např. Michna 1972, 267, obr. 5; 1977, 15-16). 


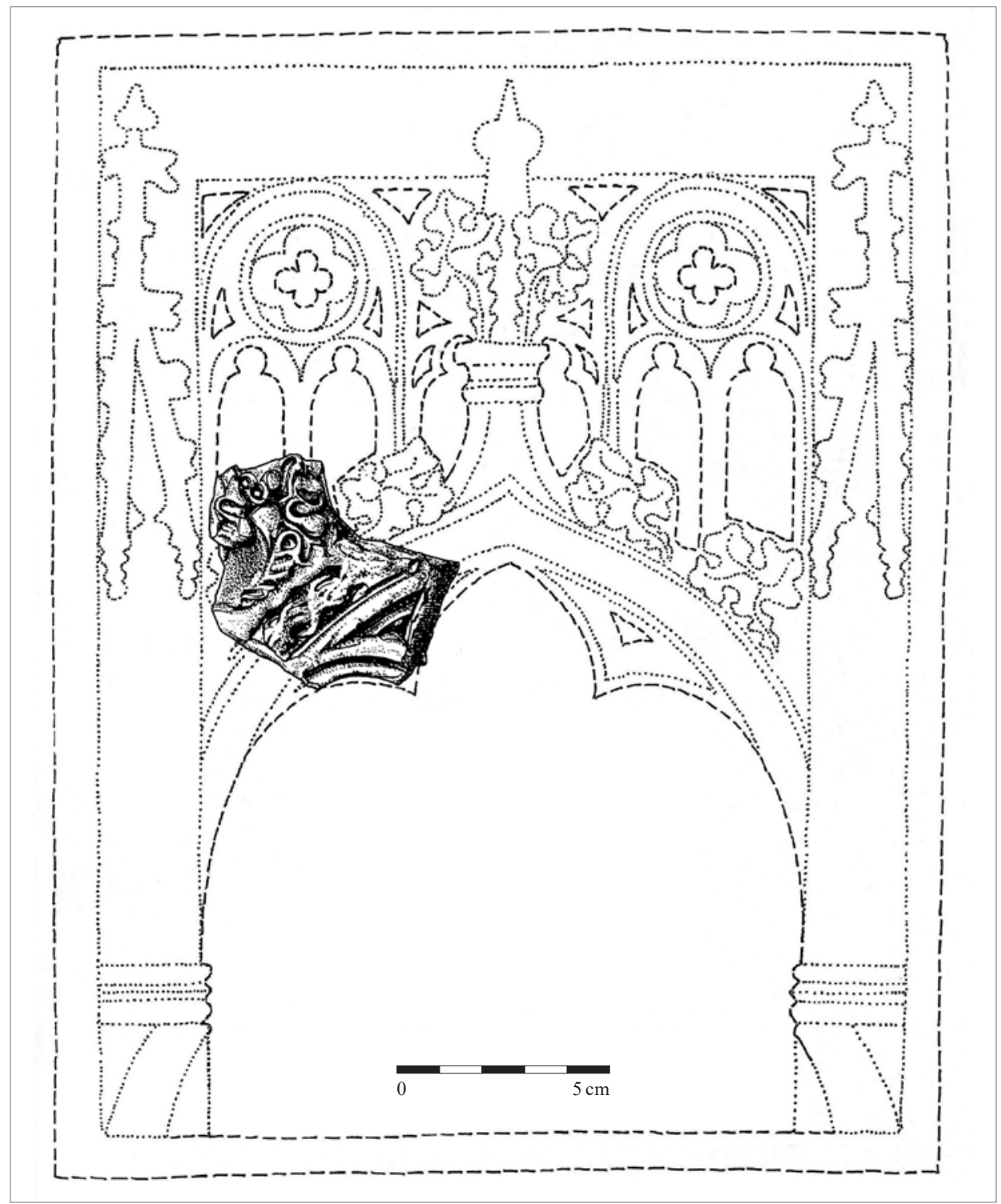

Obr. 4. Umístění litovelského zlomku na kachli Hollova typu č. 3. Upravil P. Rozsíval.

Abb. 4. Position des Kachelfragments aus Litovel in einer Kachel vom Typ Nr. 3 nach Holl. Bearbeitung P. Rozsíval.

Nálezy kachlů z této kolekce či jejich derivátů, které by mohly odpovídat litovelskému zlomku, evidujeme nejen v Uhrách, ale i v okolních zemích (srov. Holl 2004, 373-375, Abb. 25, 26). Z našeho území je známe z českých hradů Lichnice, Lipnice a nově také z Orlíka u Humpolce (Smetánka 1961, 592-597, obr. 2:4; 3:2; Kouba 1964, 193-197, obr. 11, 12; Brych 2004, 138-139, kat. č. 323; Loskotová-Dragoun-Kocman 2013, 158, obr. 46-48). Z Moravy evidujeme největší množství nálezů z areálu města Brna, z hradů Špilberku, Cimburka u Koryčan či z tvrze v Kobeřicích na Vyškovsku (např. Michna 1972, 265-268, obr. 3; 1975, 29-30; 1977, 18-19; Loskotová 2011, 88-89, 220, tab. 50:1, 2; Cejnková-Loskotová 1994, 181-188, tab. 1; Jordánková-Loskotová 2002, 559-560, obr. 5; Loskotová 2008a, 117; Procházka 1934, 11-12, obr. 23; 
Nekuda-Unger 1981, 150-152, obr. 112). Všechny tyto nálezy jsou kladeny do průběhu druhé poloviny 15. věku až přelomu 15. a 16. století (srov. Michna 1971, 256-258; 1977, 23; Jordánková-Loskotová 2002, 581; Jordánková-Loskotová-Merta 2004, 590).

Z prostoru střední Moravy disponujeme dvěma dalšími kusy z této výrazné skupiny. Patrně nejbližší litovelskému nálezu je téměř intaktní kachel z neznámé lokality uložený v etnografické podsbírce Vlastivědného muzea v Olomouci (obr. 5). Jde o zeleně glazovaný a neprořezaný kus s oslím obloukem ozdobeným sukovatkou, s kraby a kytkou mezi dvěma okny s gotickými kružbami. Po stranách se nachází dva výklenky ukončené lomenými oblouky stylizovanými fiálami s kra-

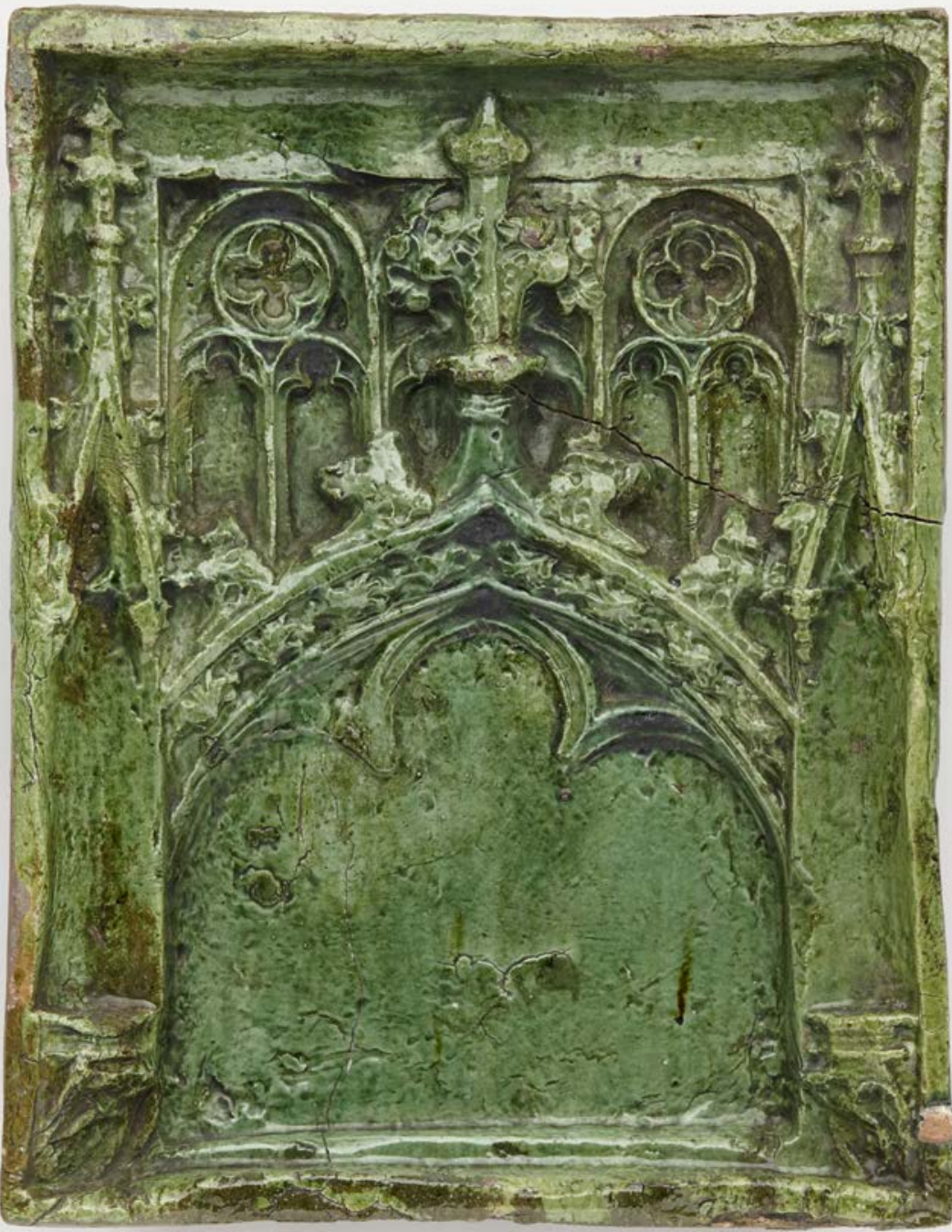

Obr. 5. Neznámá lokalita. Zeleně glazovaný kachel tzv. uherské skupiny ze sbírek Vlastivědného muzea v Olomouci. Foto P. Rozsíval.

Abb. 5. Unbekannte Fundstelle. Grün glasierte Kachel der sog. ungarischen Gruppe aus den Sammlungen des Heimatmuseums in Olmütz. Foto P. Rozsíval. 
by a křížovou kytkou. Pod konzolami obou výklenků jsou umístěny kolčí štítky, přičemž na pravém výklenku by měl být lev ve skoku a na levém snad znak orlice (Bláha 1999, 600, kat. č. 545). Je nepochybné, že jde o kachel odpovídající Hollovu typu č. 3 (srov. Holl 1958, 255, 76 kép., 291-292).

Nově se podařilo identifikovat režný zlomek s bočním výklenkem ukončeným lomeným obloukem s fiálou a malou částí oslího oblouku (obr. 6). I v tomto př́padě jej lze, s jistou dávkou opatrnosti, klasifikovat jako Hollův typ č. 3 (srov. Holl 1958, 255, 76 kép., 291-292). Jde o starý nález z kolekce kachlů a jednoho kadlubu z Loštic deponovaný v archeologické podsbírce Vlastivědného muzea v Olomouci. Bohužel se dosud nepovedlo zjistit přesnější nálezové okolnosti celého souboru. Přestože zde zastoupené kachle můžeme podle motivů na čelních vyhřívacích stěnách zařadit do 15.-17. století, netvoří patrně jeden soubor. Zároveň není jisté, zda byly nalezeny společně či na více místech v Lošticích (k tomu Hlubek 2015, 221). ${ }^{1}$

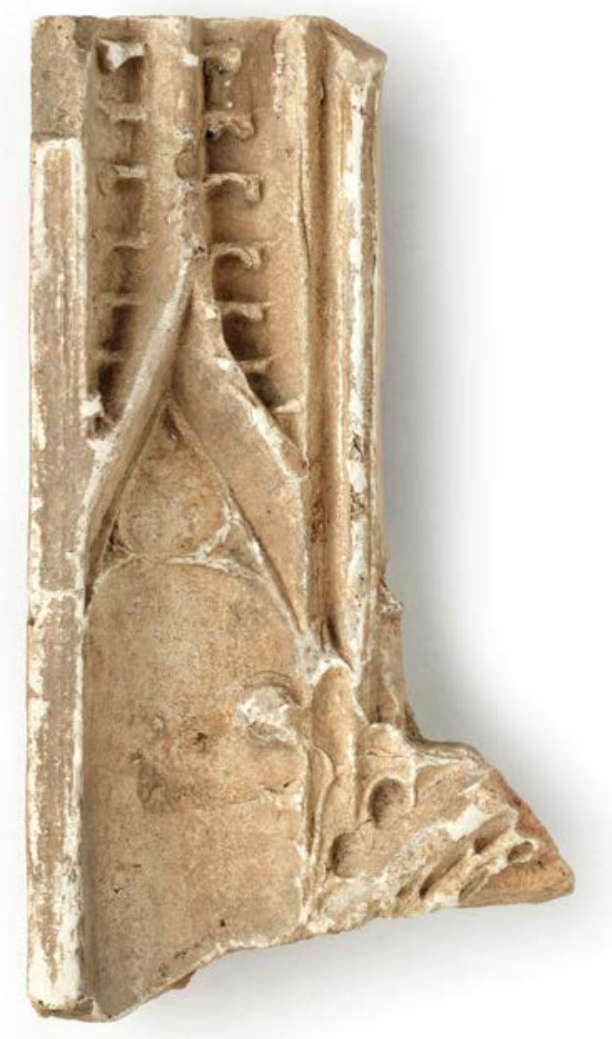

Obr. 6. Loštice. Režný zlomek kachle tzv. uherské skupiny. Foto P. Rozsíval.

Abb. 6. Loštice. Unglasiertes Kachelfragment der sog. ungarischen Gruppe. Foto P. Rozsíval.

Podobnými bočními výklenky zakončené kachle známe na střední Moravě ještě z kolekce kamnářské keramiky ze zámku v Hranicích na Moravě. V tomto souboru nalézáme paralelu v režném kachli s kavalírem $\mathrm{s}$ mečem pod nezdobeným oslím obloukem (Michna 1998, 20, kat. č. 02). Kompozice oslího oblouku, oken i výklenků je obdobná jako u výše uvedených exemplářů, ale zcela evidentně jde o domácí napodobeninu čerpající z budínských předloh (srov. Michna 1998, 12; Loskotová 2008a, 118). Je také naprosto zřejmá retardace celého reliéfu, která navíc ostře kontrastuje s dobře řemeslně provedenou výzdobou na jiných exempláŕích (srov. Michna 1998, 24, 25, 28, kat. č. 06, 07, 10). V hranickém souboru nacházíme ještě shodu v provedení dvojice gotických oken nad oslím obloukem na kachli se sedícím biskupem (Michna 1998, 22, kat. č. 04) a jako výzdobný motiv se uplatnila $\mathrm{v}$ hranickém souboru sukovatka na kachlích s heraldickými motivy (Michna 1998, 29-31, 33, kat. č. 11-13, 15; Loskotová 2008, 531, obr. 2:1-4).

Souborně můžeme konstatovat, že datování středomoravských kachlů odpovídá spíše poslední čtvrtině 15 . až počátku 16 . století (srov. Michna 1998, 12; Bláha 1999, 600). Nicméně na základě výše uvedených analogií není možné prezentovaný litovelský fragment datovat jinak než do širšího časového intervalu druhé poloviny 15 . až počátku 16 . století. $\mathrm{S}$ přihlédnutím ke kvalitě jednotlivých detailů i shodným rozměrům soudíme, že litovelský exemplář byl nejspíše vyroben z kadlubu či dřevěného pozitivu podle budínských předloh, ale vznikl mimo tuto věhlasnou dílnu.

Zlomek je možné považovat za nález vybočující z běžného standardu kamnářských výrobků $\mathrm{v}$ areálu města Litovle v uvedeném období. ${ }^{2}$ I když zatím máme k dispozici pouze jeden kus, lze

1 Tomuto souboru bude v blízké době věnována samostatná studie.

$2 \mathrm{Z}$ dosud zveřejněných nálezů pozdně středověké kamnářské keramiky z města Litovle můžeme vyzvednout pouze jeden zlomek kachle s čelní prořezávanou stěnou (srov. Hlubek 2013, 349, obr. 9:4), který lze teoreticky považovat za nadstandardní výrobek. Ostatní publikované exempláře lze označit za produkty dostupné širšímu počtu objednatelů. 
předpokládat, že otopné zařízení složené z těchto kachlů muselo v dané době představovat vysoce reprezentativní prvek celého interiéru, který si mohl dovolit pořídit pouze zámožný jedinec.

\section{Možní objednatelé tzv. rytířských kamen}

Litovel od svého založení náležela ke královským městům na Moravě. Toto postavení si udržela do konce husitských válek - po jejich ukončení se město dostalo z rozhodnutí zemského sněmu roku 1440 pod ochranu pana Karla z Vlašimi a Úsova (Elbel 2012, 26). Nedlouho po roce 1450 získal Litovel Procek z Kunštátu, včetně (nerealizované) možnosti si zde vystavět hrad. Za blíže neupřesněných okolností se roku 1465 město opět octlo v rukou Karla staršího z Vlašimi a rod pánů z Vlašimi držel město až do roku 1513, kdy vymřeli po meči a Litovel sňatkem obdržel Ladislav z Boskovic (Bezdečka 1993, 93-98; Elbel 2012, 27-28).

Jako nejpravděpodobnější objednatelé tzv. rytírských kamen by se mohli jevit zástavní držitelé města, a to bud' Karel starší z Vlašimi, nebo Procek z Kunštátu. Prvního jmenovaného lze označit za podporovatele uherského a českého krále Ladislava Pohrobka, který mu také roku 1455 ve Vídni potvrdil doživotní držbu hradu Úsova (např. Elbel 2012, 27). Na počátku 60. let 15. století se navíc Karel stal moravským podkomořím českého krále Jiřího z Poděbrad. Král mu také Litovel dal opět do zástavy. Po zisku města si zde Karel za svou rezidenci zvolil dosud neznámý dům ${ }^{3}$ a později odkoupil budovu městské rychty - dnešní radnici (Elbel 2012, 27). Ostatně ve dvoře radnice je dodnes znaková deska s erbem pánů z Vlašimi a letopočtem 1489 (Kauerová-Koudela 1998, 57; Hlobil 1999, 387, kat. č. 297). Dodejme ještě, že se Karel starší z Vlašimi za česko-uherských válek přidal na stranu Matyáše Korvína, i když je možné předpokládat, že nepatřil zrovna k jeho horlivým stoupencům (Elbel 2012, 28).

V úvahu připadá jmenovaný Procek z Kunštátu, který se těšil značné přízni Ladislava Pohrobka. Byl jmenován královským hejtmanem v Lehnici a také doprovázel krále při jeho zimním pobytu ve Vratislavi (Michna 1972, 268). Nicméně úplně nelze vyloučit ani další osoby, které sice známe z písemných pramenů, ale o jejich životních osudech už nemáme tolik informací. Máme na mysli pozdější držitele města z vlašimského rodu Karla mladšího a Jiřího, popř́ípadě od počátku 16. století pány z Boskovic. Zcela nemůžeme pominout ani možnost, že objednatelem kamen mohli být významní městští úředníci nebo zástupci litovelského patriciátu. Ostatně na dnešní Boskovicově ulici stály minimálně dva právovárečné a šenkovní domy. Můžeme jen litovat, že jejich nejstarší majitele známe až z průběhu 16. století (srov. Kauerová-Koudela 1998, 46-49; Kubešová-Richterová 1999, 172, kat. č. 86).

\section{Závěr}

Při zpracovávání souboru kachlů ze záchranného archeologického výzkumu v Litovli na Boskovicově ulici se podařilo identifikovat jeden zlomek hnědě glazovaného kachle (obr. 3 ), který lze přiřadit ke skupině kamnářské keramiky z kolekce tzv. rytírských kamen (typ 3 podle I. Holla 1958, 255, 76 kép., 291-292). Jejich původ je spojován s budínskou dílnou pracující v polovině 15. století pro uherského a českého krále Ladislava Pohrobka. Kachle této výrazné kamnářské skupiny registrujeme také na území Moravy.

Nově objevený fragment z Litovle dokládá výskyt těchto kachlů na území střední Moravy a je možné jej zařadit do průběhu druhé poloviny 15. až počátku 16. století. Zároveň jej můžeme spojovat s vysokými nároky na bydlení zdejších elit. Bohužel zatím nedokážeme přesněji určit možného objednatele otopného zařízení. Lze jen doufat, že se v budoucnu podaří v Litovli najít více exemplářu z této kolekce. Další nálezy by mohly zúžit možný okruh jejich objednatelư ${ }^{4}$ $\mathrm{v}$ tomto středomoravském městě.

3 Je pravděpodobné, že kamnářská keramika s erbem pánů z Vlašimi s jeho lokalizací nepomůže. Kachle s tímto erbem už evidujeme ze tří míst ve městě Litovli (roh ulice Masarykovy a Revoluční, ulice Boskovicova a náměstí Přemysla Otakara).

$4 \mathrm{~K}$ tomu by určitě mohlo přispět zpracování kachlového materiálu z hradu Úsova, který páni z Vlašimi drželi v letech 1416-1513 (např. Plaček 2001, 665-666). 


\section{Literatura}

BEZDĚČKA, J., 1993: Dějiny města Litovle od počátku do února 1948. 1. díl, rkp. ulož. ve Vědecké knihovně v Olomouci.

BLÁHA, J., 1999: Kachle. In: Od gotiky k renesanci. Výtvarná kultura Moravy a Slezska 1400-1550. III. díl. Olomoucko (Hlobil, I.-Perůtka, M., edd.), 596-603. Olomouc.

BRYCH, V., 2004: Kachle doby gotické, renesanční a raně barokní. Výběrový katalog Národního muzea v Praze - Stove tiles of gothic, renaissance and early baroque period. Selective catalogue of the National Museum in Prague. Praha.

CEJNKOVÁ, D.-LOSKOTOVÁ, I., 1994: Rytířská kamna na Špilberku - Knight’s Stove at Špilberk. In: Forum Brunense 1994, 181-189. Brno.

DEHNEROVÁ, H.-ŠLÉZAR, P.-ZATLOUKAL, R., 2007: Doklady středověké řemeslné zručnosti a lidové kultury našich předků z archeologických výzkumů na Olomoucku - Evidence of the Medieval Artisanal Skill and Folk Culture of Our Predecessors from Archaeological Research in the Olomouc Region. In: Památky, řemesla a lidová kultura (Kubešová, I. M., ed.), 35-46. Olomouc.

ELBEL, P., 2012: Páni z Vlašimi na Úsově a v Litovli. In: Gotické klenoty v kapli sv. Jiří v Litovli (Maňas, V., ed.), 24-39. Litovel.

FALTÝNEK, K., 2002: Litovel (okr. Olomouc), PV 43, 267-270.

- 2012: Předběžná zpráva o výsledcích archeologických dohledů prováděných v Litovli v letech 2010 a 2011 a tak trochu o smyslu archeologie vůbec, Zajímavosti z Litovelska. Ročenka Muzejní společnosti Litovelska 2011, 77-110.

- 2012a: Litovelské masné krámy ve světle historických pramenů a archeologických výzkumů - Die Fleischbänke in Litovel /Littau/ im Licht der historischen Quellen und archäologischen Forschungen. In: Sborník Národního památkového ústavu, územního odborného pracoviště v Olomouci 2012, 32-47. Olomouc.

FALTÝNEK, K.-ŠLÉZAR, P., 2006: Archeologické výzkumy sakrálních staveb v Litovli - Archäologische Forschungen der Sakralbauten in Litovel, AH 31, 303-322.

- 2014: Archeologické doklady pozůstatků komunikací a dopravních staveb v Litovli. In: Výzkum historických cest v interdisciplinárním kontextu II. (Martínek, J., ed.), 25-29. Brno.

HLOBIL, I., 1999: Portálový znak pánů z Vlašimi. In: Od gotiky k renesanci. Výtvarná kultura Moravy a Slezska 1400 - 1550. III. díl. Olomoucko (Hlobil, I.-Perůtka, M., edd.), 387. Olomouc.

HLUBEK, L., 2012: Středověké kachle z Litovle se znakem pánů z Vlašimi ve sbírkách Vlastivědného muzea v Olomouci, Střední Morava 34, 85-89.

- 2013: Soubor gotických kachlů ze sbírky bývalého Okresního vlastivědného muzea v Litovli - A set of gothic stove tiles in the collection of the former District Regional Museum at Litovel, Pravěk NŘ 21, 333-356.

- 2013a: Kachle z Litovle s portréty saských vévodů ve sbírce bývalého Okresního vlastivědného muzea v Litovli, Śląskie Spotkania Archeologiczne LV, 65-73.

- 2015: Příspěvek k výrobě kamnářské keramiky v Lošticích, Pravěk NŘ 23, 219-230.

HOLL, I., 1958: Közepkori kályhacsempék magyarországon I., Budapest régiségei XVIII, 211-300.

- 1998: Spätgotische Ofenkacheln, Acta Archaeologica Academiae Sciaentiarum Hungaricae 50, $139-214$.

- 2004: Ungarisch-polnische Beziehungen Aufgrund der Ofenkacheln (zweite Hälfte 15.-erste Hälfte 16. Jahrhundert), Acta Archaeologica Academiae Sciaentiarum Hungaricae 55, 333-375.

JORDÁNKOVÁ, H.-LOSKOTOVÁ, I., 2002: Špilberská kachlová kamna a jejich stavebníci - Špilberker Kachelöfen und ihre Besteller, AH 27, 555-587.

JORDÁNKOVÁ, H.-LOSKOTOVÁ, I.-MERTA, D., 2004: Odraz domácí války v produkci brněnských kamnářů druhé poloviny 15. století - Widerspiegelung des Heimkrieges in der Produktion der Brünner Ofensetzer in der zweiten Hälfte des 15. Jahrhunderts, AH 29, 581-597.

KAUEROVÁ, V.-KOUDELA, M., 1998: Památky staré Litovle. Olomouc.

KOUBA, J., 1964: Další doklady česko-uherských styků v oblasti středověké keramiky - Weitere Bewise fůr die Böhmisch-Ungarischen Beziehungen auf den Gebiet der Mittelaltenrichen Keramik, ČNM oddíl věd společenských CXXXIII, 185-199.

KUBEŠOVÁ, I.-RICHTEROVÁ, H., 1999: Měštanský dům. In: Od gotiky k renesanci. Výtvarná kultura Moravy a Slezska 1400 - 1550. III. díl. Olomoucko (Hlobil, I.-Perůtka, M., edd.), 172. Olomouc.

LOSKOTOVÁ, I., 2008: Rostlinné motivy reliéfních kachlů středověkého Brna - Pflenzenmotive auf Brünner mitzelalterlichen Reliefkacheln, AH 33, 529-538.

- 2008a: Architektonické motivy - Architektur. In: Krása, která hřeje. Výběrový katalog gotických a renesančních kachlů Moravy a Slezska - Schönheit, die wärmt. Gotische und renessainzeitliche Kacheln aus Mähren und Schlesien (Menoušková, D.-Měřínský, Z., edd.), 117-137. Uherské Hradiště.

- 2011: Brněnské kamnové kachle období gotiky. Rukopis disertační práce, ulož. v ÚAM FF MU. 
-2012: Nový příspěvek do kolekce tzv. rytířských kamen - A New Contribution in the Collection of "Knight Stoves", Acta historica neosoliensia 15, 192-199.

LOSKOTOVÁ, I.-DRAGOUN, B.-KOCMAN, F., 2013: Kachlové nálezy na Orlíku. In: Humpolec v zrcadle času V. Archeologie na Humpolecku (Boublík, J.-Brzoň, R.-Dragoun, B.-Hejhal, P.-Chvátal, M.-Kašpar, V.Kocman, F.-Loskotová, I.-Polanský, L.-Rous, P.-Smíšek, K.-Stan, V., edd.), 151-196. Humpolec.

LOSKOTOVÁ, I.-MENOUŠKOVÁ, D., 2010: Kachle s lvím motivem. Příspěvek ke způsobům zobrazování lva na neheraldických reliéfech kachlů na př́kladech z Brna a Uherského Hradiště - Kacheln mit einem Löwenmotiv. Ein Beitrag zu der Art der Darstellung des Löwen auf den nichtheraldischen Reliefs von Kacheln an Beispielen aus Brünn und Uherské Hradiště (Ungarisch Hradisch). In: Zaměřeno na středověk. Zdeňkovi Měřínskému k 60. narozeninám (Ungerman, Š.-Přichystalová, R., edd.), 384-394. Praha.

MENOUŠKOVÁ, D., 2009: Motiv bájného gryfa na reliéfech moravských a slezských středověkých komorových kachlů - Das Motiv des Fabeltiers Greif auf mährishen und schlesischen Blattnapfkacheln, AH 34, 225-243.

MERTA, D.-PEŠKA, M., 2010: Barbora Celská v Brně - Barbara von Cilli in Brünn. In: Zaměřeno na středověk. Zdeňkovi Měřínskému k 60. narozeninám (Ungerman, Š.-Přichystalová, R., edd.), 395-405. Praha.

MICHNA, P., 1971: Funde der ungarisch-böhmisch-polnischen Gruppe spätgotischer Kacheln in Mähren, Acta archaeologica carpathica 12, 249-259.

- 1972: Příspěvek historické archeologie k dějinám tzv. „královského domu“ v Brně - Ein Beitrag der historischen Archäologie zur Geschichte des sogennaten „Königshauses“in Brünn, VVM XXIV, 264-271.

- 1975: Odraz uhersko-moravských styků v brněnském kachlovém materiálu 15. století, Zprávy ČsSA při ČSAV XVII, sešit 1-2, 27-31.

- 1977: K vývojové a typologické charakteristice moravských středověkých kachlů - Zur Entwickklungsmässigen und Typologischen Charakteristik der Mährischen Mittelalterlichen Kacheln. In: Sborník památkové péče v Severomoravském kraji 3, 7-44. Ostrava.

- 1998: Pozdněgotické a renesanční kachle ze zámku v Hranicích - Late gothic and renaissance tiles from the Hranice Chateau. In: Pozdněgotické a renesanční kachle ze zámku v Hranicích (Miloš, S.- Sedláčková, H.-Michna, P., edd.), 7-13. Hranice.

NEKUDA, V.-UNGER, J., 1981: Hrádky a tvrze na Moravě - Hausberge und Festen in Mähren. Brno.

PLAČEK, M., 2001: Ilustrovaná encyklopedie moravských hradů, hrádků a tvrzí. Praha.

PROCHÁZKA, A., 1934: Starobylé kachle. In: Vlastivědný sborník okresu vyškovského. II. díl: Soupis památek pravěkých a historických, 3-20. Vyškov.

SMETÁNKA, Z., 1961: Základy uhersko-česko-polské skupiny pozdně gotických kachlů - Die Grundlagen der Ungarisch-Böhmish-Polnischen Gruppe der Spätgotischen Offenkacheln, PA LII, 592-598.

SMYČKA, J., 1914: Založení města Litovle (dokončení), ČMMZ XIV, 66-77, 357-365.

ŠIK, L., 1994: Litovelské paměti. Litovel.

ŠLÉZAR, P., 2005: Předběžná zpráva o objevu „Antiqua civitas“ na Starém městě v Litovli a několik poznámek k aspektům geneze města Litovle - Vorläufiger Bericht über Entdeckung der ,antiqua civitas“ in der Litoveler Altstadt und einige Bemerkungen zu den Entwicklungsaspekte der Stadt Litovel, PV 46, 103-110.

- 2008: Archeologický výzkum v suterénu budovy Městského klubu v Litovli - Archäologische Rettungsgrabung im Souterrain des Stadtklubs in Litovel (Littau), VVM LX, 167-183.

- 2008a: Kostely a sakrální stavby v Litovli - Churches and Sacred Buildings in Litovel. Archeologické památky střední Moravy 17. Olomouc.

ŠLÉZAR, P.-ŘEŘICHOVÁ, Z.-HENDRYCHOVÁ, L.-SƯVOVÁ, Z., 2008: Environmentální nálezy z vrcholně středověké a raně novověké Litovle - Environmental finds from the High Medieval and Early Post-Medieval town Litovel, Ve službách archeologie 2008/2, 197-206.

\section{Zusammenfassung}

\section{Der Fund eines Kachelfragments aus der Kollektion der sog. Ritteröfen in Litovel}

Bei der Bearbeitung der im Rahmen der in Litovel in der Straße Boskovicova durchgeführten archäologischen Rettungsgrabung entdeckten Kachelkollektion konnte das Fragment einer braun glasierten Kachel identifiziert werden (Abb. 3), das der Gruppe Ofenkeramik zugeordnet werden kann, die aus der Sammlung der sog. Ritteröfen stammt (Typ 3 nach I. Holl 1958, 255, 76 kép., 291-292). Ihr Herkunft wird mit der Mitte des 15. Jahrhunderts für den ungarischen 
und böhmischen König Ladislaus Postumus arbeitenden Werkstatt in Buda in Verbindung gebracht. Analoge Funde oder vereinfachte Derivate solcher Kacheln werden auch außerhalb von Ungarn registriert. In Tschechien sind sie von mehreren Fundstätten in Böhmen (z.B. die Burgen Lichnice, Lipnice, Orlík u Humpolce) und Mähren (z.B. Stadt Brno, die Burgen Spielberg und Cimburk u Koryčan und die Festung in Kobeřice) her bekannt; was den mittelmährischen Raum betrifft handelt es sich um einen Fund ohne nähere Fundumstände aus Loštice (Abb. 5) und um einen Fund von einer unbekannten Fundstelle, der in der Sammlung des Heimatmuseums in Olmütz aufbewahrt wird (Abb. 6), Derivate solcher Kacheln wurden auch auf dem Schloss in Hranice gefunden.

Das jüngst entdeckte Fragment aus Litovel stellt eine neu entdeckte Fundstelle mit einem belegten Vorkommen solcher Keramikerzeugnisse in der zweiten Hälfte des 15. bis zum Beginn des 16. Jahrhunderts in Mittelmähren vor. Gleichzeitig können wir es mit den hohen Ansprüchen in Verbindung bringen, welche die dortigen Eliten an das Wohnen hatte. Leider konnten wir bislang keinen möglichen Auftraggeber für die Heizanlage genauer bestimmen. Man kann nur hoffen, dass in Litovel künftig noch weitere Exemplare aus der Kollektion der sogenannten Ritteröfen gefunden werden. Durch neue Funde könnte der mögliche Umkreis an Auftraggebern in dieser mittelmährischen Stadt eingeengt werden.

Mgr. Lukáš Hlubek, Vlastivědné muzeum v Olomouci, náměstí Republiky 5, 77173 Olomouc, Česká republika,hlubek@vmo.cz

Karel Faltýnek, Národní památkový ústav, územní odborné pracoviště v Olomouci, Horní nám. 25, 77111 Olomouc, Česká republika, faltynek.karel@npu.cz

Mgr. Pavel Šlézar, Národní památkový ústav, územní odborné pracoviště v Olomouci, Horní nám. 25, 77111 Olomouc, Česká republika, slezar.pavel@npu.cz 
